\title{
Visual and Infrared Assessment of Root Colonization of Apple Trees by Phymatotrichopsis omnivora
}

\author{
W. T. Watson, C. M. Kenerley, and D. N. Appel, Department of Plant Pathology and Microbiology, Texas A\&M \\ University, College Station 77843-2132
}

\begin{abstract}
Watson, W. T., Kenerley, C. M., and Appel, D. N. 2000. Visual and infrared assessment of root colonization of apple trees by Phymatotrichopsis omnivora. Plant Dis. 84:539-543.

Root systems of 5-year-old, trellised apple trees (Malus domestica Borkh) on cv. M.7a rootstocks were assessed for the presence of fungal strands of Phymatotrichopsis omnivora (Duggar) Hennebert in two orchards in central Texas. Fungal advance within each orchard was assessed in five directions. Pathogen growth $(P<0.01)$ occurred beyond symptomatic trees along and perpendicularly across rows. In one orchard, $80 \%$ of the first asymptomatic trees were infected along rows, followed by $60 \%$ infection perpendicularly across rows. In the other orchard, there was $100 \%$ infection of the first asymptomatic trees along rows and $60 \%$ infection perpendicularly across rows. No growth was observed diagonally across rows in either orchard. Infrared readings of canopy temperature and differences between canopy temperature and air temperature were significant $(P<0.01)$ for predicting infection of asymptomatic, infected trees in one orchard. Trees were shown to have extensive taproot decay and infection of lateral roots before canopy symptoms began to develop. Root diameter appeared to have no effect on the growth of the fungus.
\end{abstract}

Additional keywords: infrared thermometer, Phymatotrichum omnivorum, plant disease control, sclerotia, soilborne pathogen

Phymatotrichopsis omnivora (Duggar) Hennebert (= Phymatotrichum omnivorum Duggar) is a soilborne pathogen reported to infect over 2,000 species of dicotyledonous plants (5). This fungus is found in calcareous soils throughout the southwestern United States and northern Mexico $(14,15,18)$. Plants are infected by mycelial strands, which grow along the root system, killing the roots and, eventually, the plant. Strands can spread rapidly from plant to plant in warm, moist soil $(12,14,19)$.

In the late 1970s, an apple (Malus domestica Borkh) industry began to develop in central Texas with the establishment of several apple orchards near Kerrville. Soon after planting, evidence of infection of trees by $P$. omnivora began to develop and become a serious problem in several orchards (1). In orchards surveyed for incidence of root rot, average tree mortality due to $P$. omnivora was approximately $15 \%$ annually (9). The pattern of disease

Corresponding author: C. M. Kenerley

E-mail: c-kenerley@tamu.edu

The use of trade names in this publication does not imply endorsement by the authors or Texas A\&M University of the products named, nor criticism of similar ones not mentioned.

Accepted for publication 5 January 2000.

Publication no. D-2000-0218-04R

(C) 2000 The American Phytopathological Society occurrence was found to be non-random and clustered within the orchards. The fungus spread within the orchards from a single focus and moved down and across rows, forming a patch of dead and dying trees (9).

Perennial crops provide unique opportunities for controlling the spread of $P$. omnivora that would not be economically feasible in annually planted row crops. Trenching, roguing, soil solarization, and soil and trunk injections with fungicides are some of the tactics that have potential for managing $P$. omnivora in orchard soils. To date, trees infected with $P$. omnivora have been identified by visual observation of disease symptoms. By the time foliar symptoms begin to develop, the tree's root system has been extensively colonized by the fungus. Because symptom expression occurs late in the disease cycle, it is unknown how far the fungus spreads beyond symptomatic trees into infected, asymptomatic trees. Without the ability to accurately locate the advancing fungus, control measures initiated behind the leading edge of the disease center would be ineffective; whereas, control options implemented far beyond the advancing fungus could result in the unnecessary loss of healthy trees. An accurate method of determining infected asymptomatic trees needs to be devised before reliable disease-management options can be implemented with maximum effectiveness.

Because $P$. omnivora kills trees by destroying their root systems, it is feasible that infected trees would have decreased transpiration and higher leaf temperatures. Aerial infrared photography has been used to identify cotton plants (Gossypium hirsutum L.) infected by $P$. omnivora $(10,17)$. Although extremely useful, aerial infrared photography can be difficult to implement and cost prohibitive for small orchards. As an alternative, infrared thermometers have proven useful for irrigation management in orchards by effectively measuring elevated leaf temperatures of water-stressed trees $(6,7)$. Infrared thermometers are relatively rapid and reliable for measuring leaf temperature, and presymptomatic infected trees can be identified in the field (7).

The primary objective of this study was to describe the spatial advancement of fungal strands beyond symptomatic trees and to determine if there was a significant difference in spread of the fungus within and across rows. This information would improve decision making when assessing potential control measures. Additionally, we were interested in assessing the effectiveness of measuring canopy temperature to locate infected trees. Lastly, we wanted to determine the condition of the root systems in relation to symptom expression and to determine whether the fungus exhibited a preference for a certain root diameter.

\section{MATERIALS AND METHODS}

The study site consisted of two separate 5-year-old bearing apple orchards located about $10 \mathrm{~km}$ southeast of Kerrville, Texas. Trees were arranged on a $3-\mathrm{m}^{2}$ spacing and were grown on an A-frame trellis system. The A-frame trellis resulted in a $60^{\circ}$ equilateral triangle where the trees were trained at an angle against the wires supporting the structure. Water availability was different for the two orchards, with one (Shaheen) under daily drip irrigation and the other (Mountaineer) non-irrigated. The soil for Shaheen was a Nuvalde silty clay and a mixed thermic Typic Haplustoll. Mountaineer soils consisted of an association of Tarpley clay, a thermic Lithic Vertic Argiustoll, and Roughcreek clay, a thermic Lithic Argiustoll. All trees sampled were planted on cv. M.7a rootstocks with various scions (cvs. Ginger Gold, Gala, Fuji, Braeburn, and Granny Smith). Detection of $P$. omnivora was determined in five directions, or scenarios, from a centrally infected tree within each orchard, including: within trellis $\left(90^{\circ} \mathrm{W}\right)$, diagonally within trellis $\left(45^{\circ} \mathrm{W}\right)$, 
along rows $\left(0^{\circ}\right)$, diagonally between trellises $\left(45^{\circ} \mathrm{B}\right)$, and between trellises $\left(90^{\circ} \mathrm{B}\right)$ (Fig. 1).

Each scenario was replicated five times in each orchard (25 groups of three to five trees/orchard). Each replicate consisted of one symptomatic tree (tree 1) on the edge of a disease center (infected within the last year) and three asymptomatic trees (Fig.
1). Tree 1 was flanked on either side by symptomatic trees and tree 2 , tree 3 , and tree 4 were the adjacent non-symptomatic trees located at progressing distances from the symptomatic tree and the edge of the disease center. Trees in the $0^{\circ}$ and $90^{\circ}$ scenarios were spaced $3 \mathrm{~m}$ apart, and trees in the $45^{\circ}$ scenarios were spaced $4 \mathrm{~m}$ apart. A total of 10 trees were arbitrarily selected

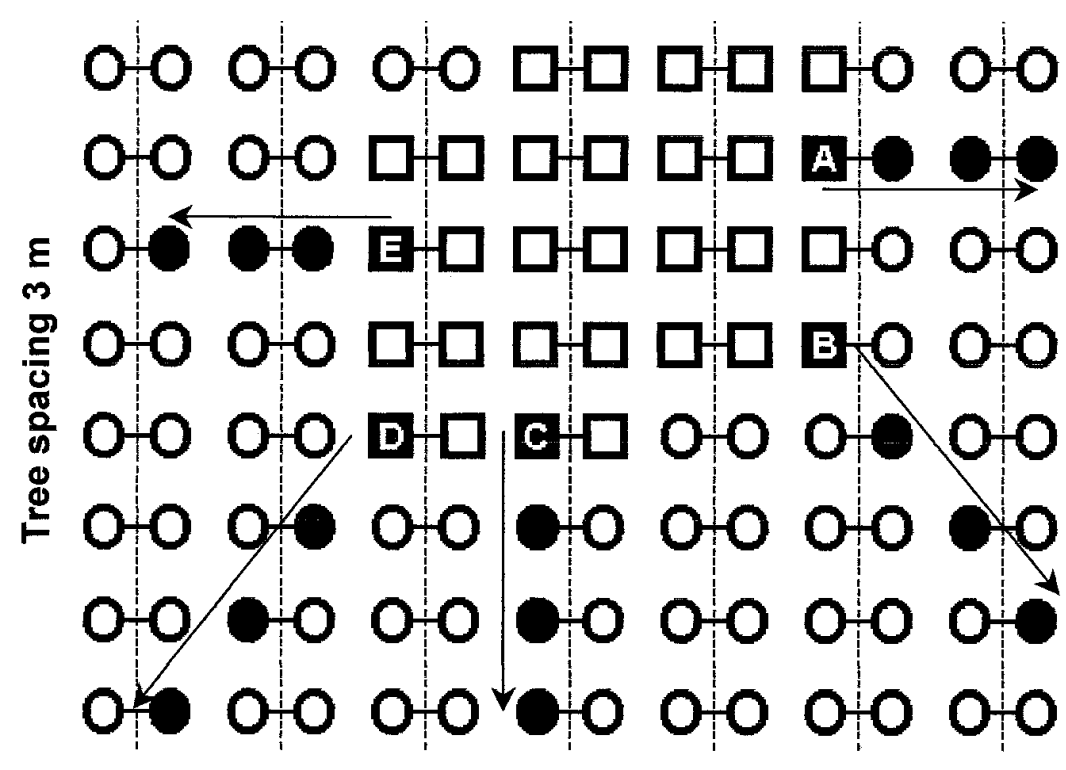

Tree spacing $3 \mathbf{m}$

Fig. 1. Representative design of five sampling scenarios within the apple orchards: (A) within trellis $\left(90^{\circ} \mathrm{W}\right)$, (B) diagonally within trellis $\left(45^{\circ} \mathrm{W}\right),(\mathbf{C})$ along rows $\left(0^{\circ}\right)$, (D) diagonally between trellises $\left(45^{\circ} \mathrm{B}\right)$, and $(\mathbf{E})$ between trellises $\left(90^{\circ} \mathrm{B}\right)$. Squares represent symptomatic trees and circles represent asymptomatic trees. Shaded squares and circles denote trees that were sampled within each scenario. The dashed line represents the center trellis wire along rows on which flanking trees are attached on an angle. Arrows indicate direction of pathogen growth and direction of trees sampled from tree 1 (symptomatic) to trees 2,3 , and 4 (asymptomatic). at least $30 \mathrm{~m}$ away from the edge of the disease centers to be used as healthy controls.

Trees were excavated with a backhoe between 18 July and 3 August 1995, the time of active symptom development within the orchard. The symptomatic tree (tree 1) and the subsequent non-symptomatic trees in a straight line perpendicular to the symptomatic trees (tree 2 , tree 3 , and tree 4) were removed. The root systems were submerged in water for several hours to loosen the soil and hand washed to remove the remaining soil from the roots. The root systems, which consisted of all roots that remained attached to the taproot after excavation, were air dried, visually observed for the presence of mycelial strands, and evaluated for root health. Trees were removed until two consecutive trees were observed which did not exhibit fungal strands on the roots. Trees were excavated within one day after taking infrared temperature measurements.

Infection was determined by observing the presence or absence of mycelial strands on the roots. Healthy roots were determined by visually estimating the percentage of healthy, uninfected lateral roots attached to the taproot. The severity of taproot decay was determined by measuring the length of the taproot showing obvious deterioration and dividing this measurement by the entire length of the taproot. Additional assessments included recording the diameters $(<5 \mathrm{~mm}, 5$ to $10 \mathrm{~mm}$, and $>10 \mathrm{~mm}$ ) and numbers of the roots colonized and the location of fungal strands on the root system in relation to the disease center.

Immediately prior to removal, canopy temperatures were recorded once for each

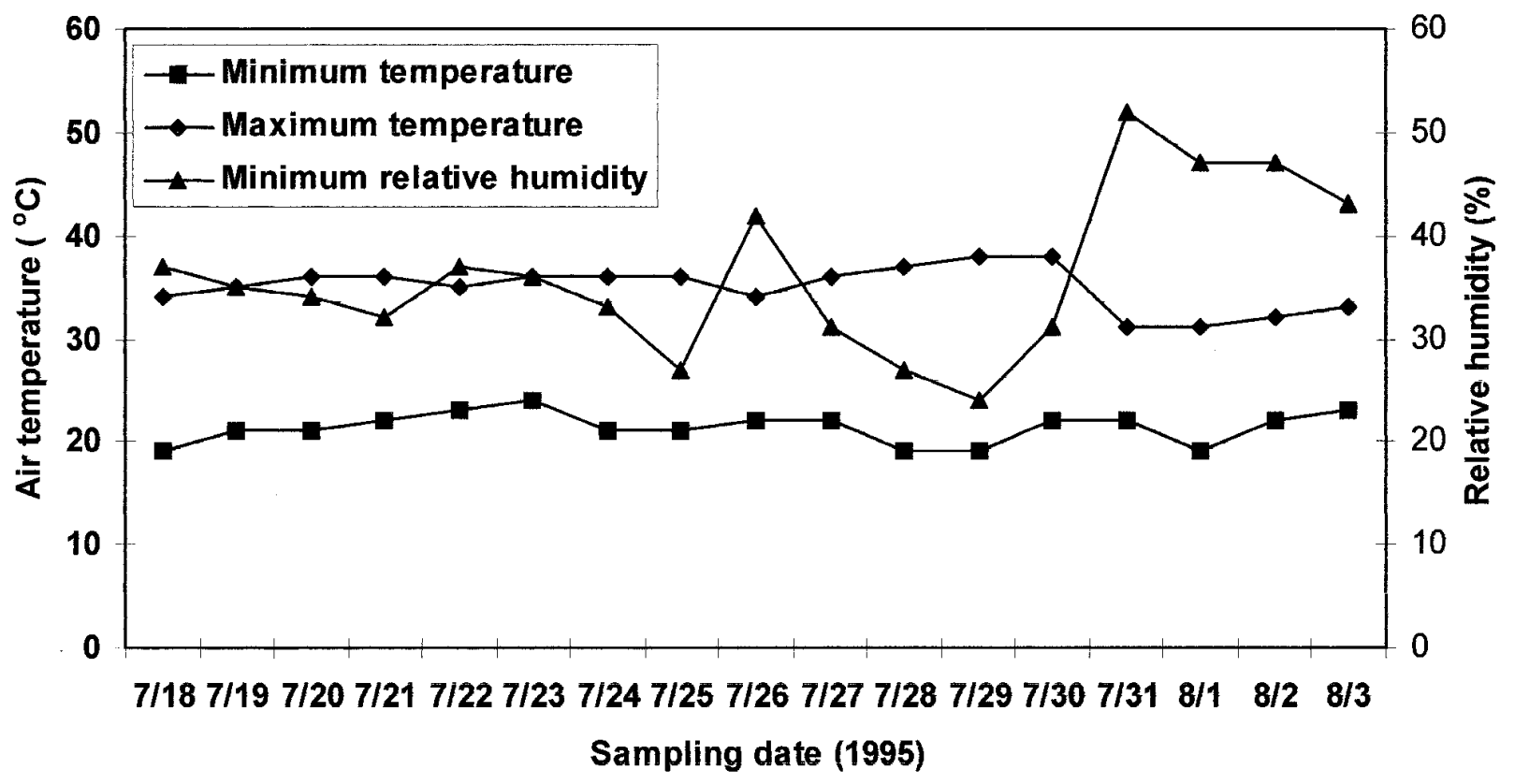

Fig. 2. Minimum and maximum temperatures $\left({ }^{\circ} \mathrm{C}\right)$ and minimum relative humidity (\%) from 18 July to 3 August 1995 . Data obtained from United States Department of Agriculture-Kerrville, Texas weather station. 
A

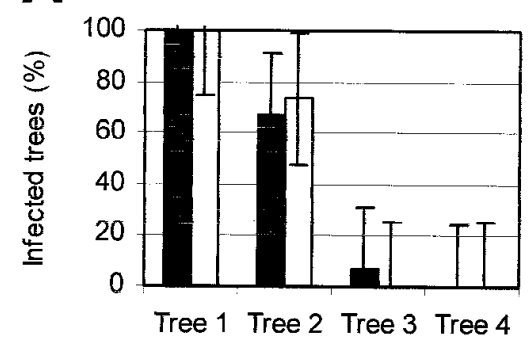

B

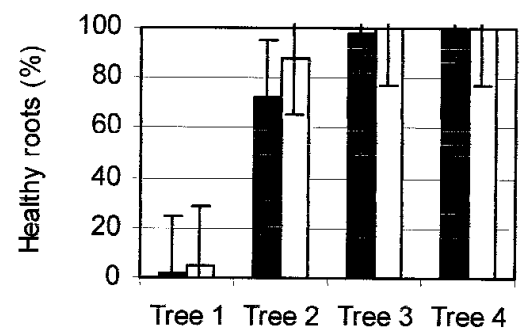

C

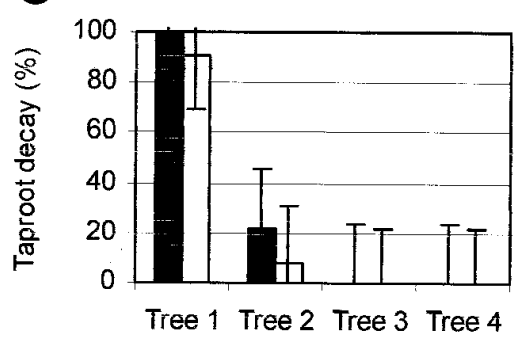

D

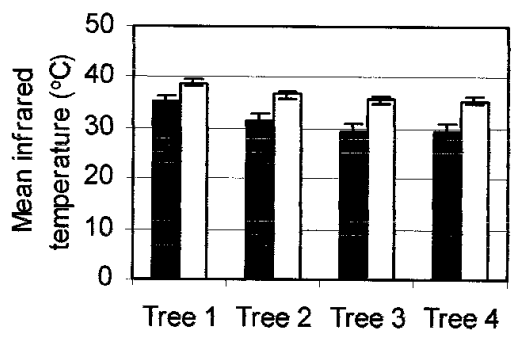

$\mathbf{E}$

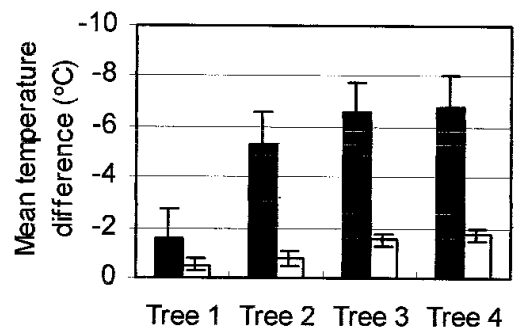

Fig. 3. The combined totals of trees sampled along rows $\left(0^{\circ}\right)$, between trellises $\left(90^{\circ} \mathrm{B}\right)$, and within trellises $\left(90^{\circ} \mathrm{W}\right)$ representing $3-\mathrm{m}$ spacing for Shaheen (solid bars) and Mountaineer (open bars). (A) Percentage of infected trees, (B) percentage of healthy roots, (C) percentage of taproot decay, (D) mean infrared canopy temperatures, and (E) mean differences between canopy temperatures and air temperatures. tree with a hand-held infrared thermometer (Model 112, Everest Interscience, Inc., Fullerton, CA). Canopy temperature and difference between canopy temperature and air temperature (temperature difference) were both measured with the infrared thermometer and compared to the rootassessment data obtained once the trees were excavated. The trees were trained into a palmate form on the trellis; therefore, the infrared target was composed of a dense $60^{\circ}$ plane of leaves in full sun. This configuration reduced false temperature readings from background shading and standardized the comparison of temperature readings between trees. Soil surface temperatures were measured with the infrared thermometer for areas between trellises and within trellises. Additional measurements of soil temperatures were monitored at $15 \mathrm{~cm}$ below the soil surface for these areas using a standard soil thermometer (Reotemp Instrument Corp., San Diego, CA).

The infrared thermometer was factory calibrated (Everest Interscience, Inc.) to an emissivity of 0.98 and an accuracy of $\pm 0.5^{\circ} \mathrm{C}$. Temperatures were recorded using the data-averaging feature of the instrument. Measurements were taken by line of sight at $1.5 \mathrm{~m}$ from the ground and $3 \mathrm{~m}$ from the tree. The instrument had a $3^{\circ}$ field of view; therefore, the infrared target area of tree canopy was approximately $15 \mathrm{~cm}$. Temperatures were recorded from 18 July to 3 August, and readings were taken between 12:00 and 2:00 P.M. each day to avoid morning and afternoon shading from the A-frame trellis. Air temperature and relative humidity recordings for the study period were taken approximately 5 miles from the orchards (United States Department of Agriculture-Kerrville, TX weather station; Fig. 2).

Regression and analysis of variance (ANOVA) using the Statistical Analysis System (SAS Institute, Cary, NC) were used to determine relationships between infrared temperatures and temperature differences of the tree canopies versus the presence of mycelial strands, percentage of healthy roots, and percentage of decayed taproot. Infrared temperatures, temperature differences, percentages of healthy, noninfected lateral roots, and percentages of taproot decay were analyzed for infected and non-infected trees using ANOVA (general linear model), and mean separa- tions were performed using least-squares with an $\alpha$ level of 0.05 . Chi-square tests were used to identify significant differences in fungal advancement by distance, direction, and size of root colonized. Significance was assessed at $P=0.05$.

\section{RESULTS}

Visual assessment of infection. To observe fungal colonization of apple root systems, a total of 201 trees were excavated. Visual observation of infected apple trees revealed that the fungus rarely progressed farther than one tree beyond the first symptomatic tree (Fig. 3A). The one exception was in Shaheen where, in one instance, the fungus progressed to two trees beyond the symptomatic tree. Examination of the combined totals of all 3-m scenarios in both orchards $\left(0^{\circ}, 90^{\circ} \mathrm{B}\right.$, and $90^{\circ} \mathrm{W}$; Fig. $1 \mathrm{~A}, \mathrm{C}$, and $\mathrm{E}$ ) revealed that $100 \%$ of the symptomatic trees (tree 1) were infected. The average number of infected trees adjacent to the first symptomatic tree for all 3$\mathrm{m}$ scenarios was $67 \%$ in Shaheen and $73 \%$ in Mountaineer.

The percentage of rootstock infection within Shaheen for tree 2 (Table 1) was $80 \%$ along rows $\left(0^{\circ}\right)$ and $60 \%$ across rows $\left(90^{\circ} \mathrm{B}\right.$ and $\left.90^{\circ} \mathrm{W}\right)(P<0.01)$. The $20 \%$ infection of tree 3 in the $90^{\circ} \mathrm{B}$ scenario represents one tree. This same trend was also seen in Mountaineer (Table 2), where 100,60 , and $60 \%$ of the first asymptomatic trees in the $0^{\circ}, 90^{\circ} \mathrm{B}$, and $90^{\circ} \mathrm{W}$ directions, respectively $(P<0.01)$, were infected. There was no detection of the pathogen diagonally across rows $\left(45^{\circ} \mathrm{B}\right.$ and $\left.45^{\circ} \mathrm{W}\right)$ beyond symptomatic trees.

Rows between trellises are subjected to full sun most of the day, while areas under trellises are shaded. Measurements of the surface temperatures of the soil taken with the infrared thermometer revealed that, at 4:00 P.M., mean temperatures ranged from $58^{\circ} \mathrm{C}$ between trellises to $39^{\circ} \mathrm{C}$ underneath the trellises (data not shown). Soil temperatures measured with a soil thermometer at $15 \mathrm{~cm}$ below the soil surface showed mean temperatures of $35^{\circ} \mathrm{C}$ between trellises and $26^{\circ} \mathrm{C}$ under trellises.

There appeared to be no significant relationships between the location of strands on the root system and the effect of root size on colonization of the fungus. No differences in colonization by the fungus where found in the three root diameters examined $(<5 \mathrm{~mm}, 5$ to $10 \mathrm{~mm}$, and $>10$

Table 1. Percentage of trees exhibiting fungal strands by scenario for Shaheen ${ }^{\mathrm{y}}$

\begin{tabular}{lcccc}
\hline Scenarios $^{\mathbf{z}}$ & Tree 1 $(\boldsymbol{\%})$ & Tree 2 (\%) & Tree 3 $(\boldsymbol{\%})$ & Tree 4 (\%) \\
\hline Along row $\left(0^{\circ}\right)$ & 100 & 80 & 0 & 0 \\
Between trellises $\left(90^{\circ} \mathrm{B}\right)$ & 100 & 60 & 20 & 0 \\
Within trellis $\left(90^{\circ} \mathrm{W}\right)$ & 100 & 60 & 0 & 0 \\
Diagonally between trellises $\left(45^{\circ} \mathrm{B}\right)$ & 100 & 0 & 0 & 0 \\
Diagonally within trellis $\left(45^{\circ} \mathrm{W}\right)$ & 100 & 0 & 0 & 0 \\
\hline
\end{tabular}

y Tree $1=$ symptomatic trees; trees 2,3 , and $4=$ asymptomatic trees.

z Scenarios represent spatial direction of sampled trees within and across rows. Each scenario is replicated five times. 
$\mathrm{mm}$ ). Mycelial strands were found equally distributed on all root diameters of infected trees, and infected roots were usually distributed evenly throughout the root system once the pathogen reached the taproot. In the few instances where trees were just starting to be invaded by the fungus, mycelial strands were found only on the side of the root system closest to the adjacent infected tree.

Relationships between infected trees and percentage of healthy roots and percentage of taproot decay were observed. In both orchards, there was a progressive increase in healthy roots and a progressive decrease in taproot decay in relation to distance from tree 1 (Fig. 3B and C). In Shaheen, symptomatic trees exhibited $98 \%$ taproot decay and $2 \%$ healthy roots, and asymptomatic infected trees had $27 \%$ taproot decay and $60 \%$ healthy roots (Table 3 ). The same general trend for percentage of taproot Mountaineer, with 82 and $7 \%$ for symptomatic trees and 11 and $85 \%$ for nonsymptomatic infected trees (Table 4).

Infrared assessment of infection. There was a significant association in Shaheen between infrared canopy temperature and infection $(P<0.01)$. Leaves became progressively cooler when moving away from the edge of the disease center (Fig. $3 \mathrm{D}$ and $\mathrm{E})$. The relationships between infrared temperature and infection and symptom expression of trees sampled in all decay and healthy roots was seen in

scenarios for Shaheen are outlined in Table 3. Mean temperatures for symptomatic trees, asymptomatic infected trees, and non-infected trees in Shaheen were 34.31, 31.57 , and $29.29^{\circ} \mathrm{C}$, respectively. For Mountaineer, mean infrared temperatures were $38.63^{\circ} \mathrm{C}$ for symptomatic trees, $35.64^{\circ} \mathrm{C}$ for asymptomatic infected trees, and $36.36^{\circ} \mathrm{C}$ for non-infected trees. There was not a significant association between the infrared temperatures of asymptomatic infected and non-infected trees for Mountaineer (Table 4).

Similar relationships were observed for the differences between canopy temperature and air temperature. Canopy temperatures became cooler as trees progressed from symptomatic to asymptomatic infected to non-infected. The distribution of temperature differences for symptomatic, asymptomatic infected, and non-infected trees for all scenarios within Shaheen is shown in Table 3. For non-infected trees in the irrigated orchard, the leaf temperature was lower than the air temperature. The mean temperature differences for trees in Shaheen were $-2.37^{\circ} \mathrm{C}$ for symptomatic trees, $-5.05^{\circ} \mathrm{C}$ for asymptomatic infected trees, and $-6.94^{\circ} \mathrm{C}$ for non-infected trees $(P<$ 0.01). For Mountaineer (Table 4), mean temperature differences were $0.91{ }^{\circ} \mathrm{C}$ for symptomatic trees, $-0.72^{\circ} \mathrm{C}$ for asymptomatic infected trees, and $-1.15^{\circ} \mathrm{C}$ for noninfected trees. There was not a significant relationship between the temperature dif-

Table 2. Percentage of trees exhibiting fungal strands by scenario for Mountaineer ${ }^{y}$

\begin{tabular}{lcccc}
\hline Scenarios $^{\mathbf{Z}}$ & Tree 1 (\%) & Tree 2 $(\boldsymbol{\%})$ & Tree 3 (\%) & Tree 4 (\%) \\
\hline Along row $\left(0^{\circ}\right)$ & 100 & 100 & 0 & 0 \\
Between trellises $\left(90^{\circ} \mathrm{B}\right)$ & 100 & 60 & 0 & 0 \\
Within trellis $\left(90^{\circ} \mathrm{W}\right)$ & 100 & 60 & 0 & 0 \\
Diagonally between trellises $\left(45^{\circ} \mathrm{B}\right)$ & 100 & 0 & 0 & 0 \\
Diagonally within trellis $\left(45^{\circ} \mathrm{W}\right)$ & 100 & 0 & 0 & 0 \\
\hline
\end{tabular}

${ }^{\mathrm{y}}$ Tree 1 = symptomatic trees; trees 2, 3, and 4 = asymptomatic trees.

${ }^{\mathrm{z}}$ Scenarios represent spatial direction of sampled trees within and across rows. Each scenario is replicated five times.

Table 3. Mean infrared temperatures; temperature differences; percentages of healthy, non-infected lateral roots; and percentages of taproot decay for infected and non-infected trees in Shaheen ${ }^{\mathrm{z}}$

\begin{tabular}{lccrc}
\hline Tree condition & $\begin{array}{c}\text { Infrared } \\
\text { temperature }\left({ }^{\circ} \mathbf{C}\right)\end{array}$ & $\begin{array}{c}\text { Temperature } \\
\text { difference }\left({ }^{\circ} \mathbf{C}\right)\end{array}$ & $\begin{array}{c}\text { Healthy roots } \\
(\boldsymbol{\%})\end{array}$ & $\begin{array}{c}\text { Taproot decay } \\
(\boldsymbol{\%})^{\mathbf{z}}\end{array}$ \\
\hline Infected (symptomatic) & $34.31 \mathrm{a}$ & $-2.37 \mathrm{a}$ & $1.75 \mathrm{a}$ & $98.06 \mathrm{a}$ \\
Infected (asymptomatic) & $31.57 \mathrm{~b}$ & $-5.05 \mathrm{~b}$ & $59.89 \mathrm{~b}$ & $27.01 \mathrm{~b}$ \\
Non-infected & $29.29 \mathrm{c}$ & $-6.94 \mathrm{c}$ & $100.00 \mathrm{c}$ & $0.00 \mathrm{c}$ \\
\hline
\end{tabular}

${ }^{\mathrm{z}}$ Within-column means followed by the same lower case letter are not significantly different at $P<$ 0.05 .

Table 4. Mean infrared temperatures; temperature differences, percentages of healthy, non-infected lateral roots; and percentages of taproot decay for infected and non-infected trees in Mountaineer ${ }^{\mathrm{z}}$

\begin{tabular}{lcccc}
\hline Tree condition & $\begin{array}{c}\text { Infrared } \\
\text { temperature }\left({ }^{\circ} \mathbf{C}\right)\end{array}$ & $\begin{array}{c}\text { Temperature } \\
\text { difference }\left({ }^{\circ} \mathbf{C}\right)\end{array}$ & $\begin{array}{c}\text { Healthy } \\
\text { roots }(\%)\end{array}$ & $\begin{array}{c}\text { Taproot } \\
\text { decay }(\%)\end{array}$ \\
\hline Infected (symptomatic) & $38.63 \mathrm{a}$ & $0.91 \mathrm{a}$ & $6.75 \mathrm{a}$ & $82.06 \mathrm{a}$ \\
Infected (asymptomatic) & $35.64 \mathrm{~b}$ & $-0.72 \mathrm{~b}$ & $85.23 \mathrm{~b}$ & $11.16 \mathrm{~b}$ \\
Non-infected & $36.36 \mathrm{~b}$ & $-1.15 \mathrm{~b}$ & $99.70 \mathrm{c}$ & $0.00 \mathrm{~b}$ \\
\hline
\end{tabular}

${ }_{\mathrm{z}}$ Within-column means followed by the same lower case letter are not significantly different at $P<$ 0.05 . ferences of asymptomatic infected and noninfected trees for Mountaineer (Table 4).

\section{DISCUSSION}

Much of the previous research on $P$. omnivora has focused on diseases of annual crops $(22,25)$. Different rates of fungal advance for $P$. omnivora have been demonstrated down rows and across rows in cotton fields $(8,13)$. These studies strongly suggest a correlation between root distribution and growth of the pathogen within a field. Excavation of apple rootstocks in this study supports the previous hypotheses $(8,9,13,19)$ that growth of the fungus from plant to plant occurs along overlapping roots or over short distances between roots that are in close proximity. A study of root distribution within these orchards showed greater root development along rows than across rows, with little overlap of roots beyond $2 \mathrm{~m}$ from the trees (W. T. Watson, unpublished). This could account for the lack of diagonal growth of the fungus where trees were spaced $4 \mathrm{~m}$ apart.

Previous studies have shown a correlation between soil moisture and growth of P. omnivora $(11,26)$. Because trees in Shaheen are drip irrigated along rows, it is possible that increased soil moisture accounts for the increase in infection percentages along rows in comparison to other directions. It is interesting to note, however, that there is little difference in the pattern of infected trees within scenarios between Shaheen, which was irrigated, and Mountaineer, which was not irrigated.

It was originally hypothesized that there might be a difference in growth of the pathogen between trellises and under trellises due to the difference in soil temperatures of these two areas. Previous studies have demonstrated that the optimum temperature for growth of $P$. omnivora in soil is $28^{\circ} \mathrm{C}$ (16). In controlled studies (C. Kenerley, unpublished), soil temperatures of $36^{\circ} \mathrm{C}$ for $48 \mathrm{~h}$ resulted in an $80 \%$ mortality of sclerotia. Other researchers have observed minimal strand development in soil temperatures above $32^{\circ} \mathrm{C}(26)$. These findings suggest that other plant-diseasecontrol measures, such as radio frequency heating or soil solarization (4), which have been useful in managing other soilborne pathogens, may prove to be viable management strategies for $P$. omnivora in perennial crops.

Soil-temperature differences within the orchards appeared to have little effect on the rate of growth of the fungus. It is possible that most of the fungal growth during periods of high soil temperature follows a nocturnal cycle. Another possibility is that fungal growth and infection are greatest during the cooler seasons of the year, with trees exhibiting symptoms later in the spring and summer when evapotranspiration exceeds the ability of the infected root system to supply sufficient water to the canopy. This latter hypothesis is possible 
because viable strands of $P$. omnivora were isolated from the roots of diseased trees in these orchards throughout the dormant season during the winter of 1994 to 1995 (C. Kenerley, unpublished).

The correlation between infected trees and infrared temperatures in Shaheen indicates that an infrared temperature scanner may be an effective tool for assisting in the identification of asymptomatic apple trees infected with $P$. omnivora. The accuracy of older models of infrared thermometers has been shown to be affected by environmental factors $(6,7)$. These older models require fairly uniform environmental conditions to obtain reliable results. However, newer models are designed to measure and compensate for fluctuations in humidity, solar radiation, and other factors that may affect the accuracy of results.

Measuring the difference in canopy temperature and air temperature appears to give more reliable results than canopy temperature alone. This is due in large part to the arid climate of central Texas. In arid climates, canopy temperatures can be several degrees below air temperature whereas, in humid areas, canopy temperatures tend to be at or above air temperatures $(6,7)$. Previous studies have shown that there can be wide variations in leaf temperatures of adjacent plants in water-stressed sites as compared to adjacent plants in sites with adequate soil moisture (7).

In annual crops, management strategies for $P$. omnivora focus on reducing numbers of viable sclerotia in the soil each season by deep plowing, crop rotation, and other methods (14,20-23). Perennial crops pose different challenges for managing $P$. omnivora. It is suspected that mycelial strands, not sclerotia, are responsible for growth of the pathogen throughout perennial crops from season to season (2). Due to the relative permanency of perennial crops, new disease-management techniques need to be developed.

Trenches and root barriers have been used to control plant-to-plant spread of Armillaria mellea (Vahl:Fr.) P. Kumm. in orchard soils of several types of perennial crops (24). Also, roguing trees has been demonstrated to be an effective barrier to slow or eliminate the growth of root pathogens between trees (3). Apples represent a high-value crop; therefore, these types of costly management strategies may be feasible. If $P$. omnivora moves within an orchard by moving from tree to tree along live root systems, then trenching, roguing, or wider tree spacings may prove to be effective means of controlling the spread of the pathogen within an orchard. Detection of fungal colonization of symptomless apple trees adjacent to symptomatic trees is a necessity before procedures can be implemented to control P. omnivora in apple orchards.

Based on the results of these studies, disease-control measures for $P$. omnivora should be implemented at least two trees beyond a symptomatic tree. Curative chemical or biological control measures for symptomatic trees would probably be ineffective due to the extensive damage that has occurred to the tree's root system by the time symptoms have developed. All symptomatic trees and some asymptomatic, infected trees in this study had extensive decay of the main taproot, and few viable roots remained. These trees would be poor candidates for curative diseasecontrol measures because they would not likely recover from the massive root losses. To maximize control efforts, trees should be treated preventatively in order to achieve effective control.

\section{ACKNOWLEDGMENTS}

We thank T. Goode of Turtle Creek Orchards, Inc., for technical assistance.

\section{LITERATURE CITED}

1. Acuff, G. 1993. Blazing a trail for Texas apples. West. Fruit Grow. 113:6-7.

2. Alderman, S. C., and Hine, R. B. 1982. Vertical distribution in soil and induction of disease by strands of Phymatotrichum omnivorum. Phytopathology 72:409-412.

3. Appel, D. N. 1994. Identification and control of oak wilt in Texas urban forests. J. Arboric. 20:250-258.

4. Ashworth, L. J., Jr., and Gaona, S. A. 1982. Evaluation of clear polyethylene mulch for controlling Verticillium wilt in established pistachio nut groves. Phytopathology 72:243246.

5. Blank, L. M. 1953. The rot that attacks 2000 species. Plant Diseases. Pages 298-301 in: U.S. Dep. Agric. Yearb. A. Stefferund, ed. U.S. Gov. Print. Off. Washington, DC.

6. Hatfield, J. L. 1990. Measuring plant stress with an infrared thermometer. HortScience 25:1535-1538.

7. Jackson, R. D. 1982. Canopy temperature and crop water stress. Pages 43-85 in Advances in Irrigation, Volume 1. Academic Press, New York.

8. Jeger, M. J., Kenerley, C. M., Gerik, T. J., and Koch, D. O. 1987. Spatial dynamics of Phymatotrichum root rot in row crops in the blackland region of North Central Texas. Phytopathology 77:1647-1656.

9. Kenerley, C. M., Ivors, K., Appel, D., and Nelson, S. 1994. Spatial and temporal dy- namics of epidemics in apple orchards caused by Phymatotrichum omnivorum. (Abstr.) Phytopathology. 84:1142.

10. Kenerley, C. M., and Jeger, M. J. 1992. Fungal diseases of the root and stem, Pages 161190 in Cotton Diseases. R. J. Hillocks, ed. CAB International, Wallingford, UK.

11. Kenerley, C. M., White, T. L., Jeger, M. J., and Gerik, T. J. 1998. Sclerotial formation and strand growth of Phymatotrichopsis omnivora in minirhizotrons planted with cotton at different soil water potentials. Plant Pathol. 47:259-266.

12. King, C. J., Loomis, H. F., and Hope, C. 1931. Studies on sclerotia and mycelial strands of the cotton root-rot fungus. J. Agric. Res. 42:827-840.

13. Koch, D. O., Jeger, M. J., Gerik, T. J., and Kenerley, C. M. 1987. Effects of plant density on progress of Phymatotrichum root rot in cotton. Phytopathology 77:1657-1662.

14. Lyda, S. D. 1978. Ecology of Phymatotrichum omnivorum. Annu. Rev. Phytopathol. 16:193209.

15. Lyda, S. D., and Burnett, E. 1970. Sclerotial inoculum density of Phymatotrichum omnivorum and development of Phymatotrichum root rot in cotton. Phytopathology 60:729-731.

16. Lyda, S. D., and Burnett, E. 1971. Influence of temperature on Phymatotrichum sclerotial formation and disease development. Phytopathology 61:728-730.

17. Nixon, P. R., Lyda, S. D., Heilman, M. D., and Bowen, R. L. 1975. Incidence and control of cotton root rot observed with color infrared photography. Tex. Agric. Ext. Serv. Miscellaneous Publ. 1241.

18. Percy, R. G. 1983. Potential range of Phymatotrichum omnivorum as determined by edaphic factors. Plant Dis. 67:981-983.

19. Percy, R. G., and Rush, C. M. 1985. Evaluation of four upland cotton genotypes for a rate-limiting resistance to Phymatotrichum root rot. Phytopathology 75:463-466.

20. Rea, H. E. 1933. Effect of tillage on eradication of cotton root rot. J. Am. Agron. Soc. 25:764-771.

21. Rea, H. E. 1939. Control of cotton root rot in the blackland region of Texas. Tex. Agric. Exp. Stn. Bull. 573

22. Rogers, C. H. 1937. Effect of three- and fouryear rotations on cotton root-rot in the Central Texas Blacklands. J. Am. Agron. Soc. 26:313318.

23. Rogers, C. H. 1942. Cotton root rot studies with special reference to sclerotia, cover crops, rotations, tillage, seeding rates, soil fungicides and effects on seed quality. Tex. Agric. Exp. Stn. Bull. 614.

24. Shaw, C. G., and Kile, G. A. 1991. Armillaria Root Disease. U. S. Dep. Agric. For. Serv. Agric. Handb. No. 691.

25. Streets, R. B., and Bloss, H. E. 1973. Phymatotrichum root rot. Am. Phytopathol. Soc. Monogr. No. 8

26. White, T. L. 1988. The in-situ effects of soil water potential on Phymatotrichum omnivorum sclerotial function and germination. MS Thesis, Texas A\&M University, College Station. 